\title{
Assessment of Beekeeping System, Constraints and Opportunities in Selected Districts of West Hararghe Zone, Oromia Regional State, Ethiopia
}

\author{
Sudi Dawud*, Degefa Negessa, Kassahun Lemi, Dereje Tsegaye \\ Oromia Agricultural Research Institute, Mechara Agricultural Research Center, Mechara, Ethiopia \\ Email address: \\ sudidawud@gmail.com (S. Dawud) \\ ${ }^{*}$ Corresponding author \\ To cite this article: \\ Sudi Dawud, Degefa Negessa, Kassahun Lemi, Dereje Tsegaye. Assessment of Beekeeping System, Constraints and Opportunities in \\ Selected Districts of West Hararghe Zone, Oromia regional State, Ethiopia. International Journal of Animal Science and Technology. \\ Vol. 4, No. 2, 2020, pp. 17-23. doi: 10.11648/j.jjast.20200402.11
}

Received: May 21, 2020; Accepted: June 5, 2020; Published: June 28, 2020

\begin{abstract}
The study was conducted two districts (Daro Labu \& Gemmachis) of western Hararghe Zone with the objective of identifying beekeeping production systems and constraints in the area. For this study 6 Peasant Associations (PAs) were selected on the bases of beekeeping potential. 90 beekeepers were interviewed using pre tested semi-structured questionnaires and PRA were also used for 55 non-beekeepers. Data were analyzed using SPSS version 13. In the survey area among the beekeepers interviewed almost all farmer possess different types of traditional hive where only $26.7 \%$ and $2.22 \%$ owned modern box hive and transitional hive respectively. About $96.67 \%$ of the respondents categorize their colonies based on body size, color, swarming rate, honey production and ability to enemy protection. $80 \%$ of the interviewed farmers prefer "Red" and "Shumbure" colored bees. The beekeepers have good knowledge in colony management - feeding, watering and pest and predator caring. In all surveyed areas, honey harvested once a year from end of September to November (main honey flow) and sometimes April to May (minor honey flow). The average honey yield from traditional, transitional \& box hive per harvest were $6.4 \pm 2.63,8 \pm 2.83$ and $13.9 \pm 4.04 \mathrm{~kg}$ respectively. There are different kinds of bee pests and predators in the area as small ant, birds, wax moth and others. $92.23 \%$ of respondent stated that as the trend of beekeeping is decreasing due to a number of factors. In our survey major beekeeping constraints in the area were also identified as lack of extension services, lack of improved beekeeping technologies, lack of man power, Lack better performer line, lack of bee forage. From this study it was realized that, there is potential of beekeeping in the zone but the production system still under traditional way where it needs further intervention of NGOs, Conservers, Researchers and private organizations to improve production system and exploit resource from this sub sector.
\end{abstract}

Keywords: Honeybees, Beekeepers, Production System, Constraints, West Hararghe

\section{Background and Justification}

Ethiopia is a leading honey producer in Africa and one of the ten largest honey producing countries in the world. Ethiopia has a share of around $23.58 \%$ and $2.13 \%$ of the total Africa and world honey production respectively [2]. Due to its wide climatic and edaphic variability, Ethiopia is a home to some of the most diverse flora and fauna in Africa that provide surplus nectar and pollen source to foraging bee colonies [10]. The ideal climatic conditions and diversity of floral resources allow the country to sustain around 10 million honeybee colonies, of which 7 million are kept in local beehives by farmers, and the remaining exist in the forests as wild colonies. This makes the country to have the highest bee density in Africa [2, 14]. Despite the favorable agro ecology for honey production and the number of bee colonies the country is endowed with, the level of honey production and productivity in the country is remain low. One of the prominent factors for this low honey and productivity is traditional hives. Ethiopia has the potential to 
produce 500,000 tonnes of honey per year and 50,000 tonnes of beeswax per annual, but currently production is limited to 43,000 tonnes of honey and 3,000 tonnes of beeswax [13]. Ethiopia has immense natural resources for beekeeping activity. However, like any other livestock sector, this sub sector has been seriously devastated by complicated constraints. the prevailing production constraints in the beekeeping sub sector of the country would vary depending on the agro ecology of the areas where the activities is carried out [5]. Ethiopia is a country of diversified climate, weather condition, topography and Agro ecological zones with different farming system; which makes the country very conducive for the growth of complex wild flowering plant species and cultivated food crops both annual and perennials which flowers at different season of a year. Thus all these potential resource enables the country to keep a large number of bee colonies $[9,1]$. This naturally conducive environment and the resources, which are important for the honeybee products and the experience of the local farmer beekeepers, have put the country on the first rank in honeybee colony population and hive products (honey and bees' wax) in Africa and tenth in the world [9].

However, as to the resources potential of the country, the productivity and production from this sub sector is below expectation. The major constraints that affect beekeeping sub-sector in Ethiopia are: lack of beekeeping knowledge, shortage of skills man power, shortage of bee equipment, pests and predators, pesticide threat, poor infrastructure development, shortage of bee forage and lack of research extension [11]. The contribution of honey and bees' wax to the world market is under the management of the tradition local beekeepers, which is extensive system - more than $97 \%$ are still use this system. As compared to other livestock as well as crop sub sectors, the utilization of the available resource and extension service delivery is very poor in beekeeping.

Thus, the management practice, type of hive used, methods and storage of the product have significantly affected the quality and physically unattractiveness and hence, ultimately reduce the market prices of the product, honey.

Anon, 2005 pointed out that no amount of research will lead to sustainable agricultural development, if the countries in Africa don't address the constraint to sustainable agriculture. Identification of production system, available resource, indigenous knowledge and production constraints is the basic step to improve the traditional production system through development \&/or adoption of improve technologies that consider the traditional indigenous knowledge.

Therefore, this study was proposed to exploit the major honey production constraints, production potential, indigenous knowledge on management practice, in selected districts of West hararghe Zone of Oromia regional State.

\section{Methods \& Materials}

The study was conducted in Daro Labu and Gemmachis districts of western Hararghe Zone selected based on potentiality for beekeeping. From each district purposively three potential peasant associations were selected. Accordingly a total of six peasant associations were selected for the study purpose. Then purposively after taking the list of beekeepers, fifteen beekeepers from each peasant association were randomly selected and a total of 90 beekeepers interviewed for the study. The beekeepers were interviewed with formal questionnaires; and PRA was used for 55 (26 \& 29 From Gemmachis and Daro Labu respectively) none beekeepers. Accordingly a total of 145 farmers interviewed for the survey purpose. All necessary information on beekeeping like: socio-economic description of the household, Traditional Hive Construction and its distribution, Traditional Colony naming, Honeybee Management Practice, honey flow season identification, production, processing and storage, Honey Marketing and problems related to beekeeping and finally the collected Data were analyzed using SPSS version 13. The beekeepers have developed highly appreciable management practices: feeding, watering, pest and predators control system and they are highly aware of the mutual relationship between bees and vegetation as compared non beekeepers.

\section{Results \& Discussion}

\subsection{Socio-economic Description of the Household}

According to the sample result $65 \%, 31.7 \%$ and $3.3 \%$ of the respondent were illiterate, grade 1-8 and have got adult education respectively. From the educated respondents $67.8 \%$ of them were from Gemmachis. $70 \%$ of them fall in $18-40$ years old and the average age was 37.65 ranging from 18-69 year and $10 \%$ of them were female. Concerning gender roll and participation, $25.6 \%$ of the respondents replied that male and female equally participate in beekeeping, while the rest considers as only of men job. $83.33 \%$ are paired $5.55 \%$ are divorce where most of them (the divorced) were female. Average number of children per household was 10.84 ranging from $4-27.80 \%$ of the surveyed farmers were Islam. Almost all of the respondent have no source of income except agriculture; and the average land owned per household is $1.35 \pm 0.945$ ha ranging from $0.25-4$ ha and was not significant $(\mathrm{P}<0.01)$ between districts except in Oda Biyyo peasant association which is an agro pastoral.

\subsection{Traditional Hive Construction, Possession, Hive Placement and Distribution of Transitional and Modern Hives}

Farmers construct hive from different materials; like climber, mud, log, and bark. A newly constructed hive is smoothen/plastered by animal dung. Among the sample beekeepers, the average number of traditional hive per farmer was $8.01 \pm 5.19$ (range 2-27), out of which almost only half occupied by bees $(48.78 \%$, ranging $1-15)$. With this figure there is a slight difference between the surveyed districts (not significant at $\mathrm{p} \leq 0.05$ ). However, the distribution of improved 
hive differs between districts. Among the beekeepers interviewed only $26.7 \%$ and $2.22 \%$ owned modern box hive and Chefeqa top bar hive respectively, where $80 \%$ of improve box hive and $100 \%$ of transitional hive found in Gemmachis. Of the total improved hive owned, only $23 \%$ have occupied by bees; concerning this very few farmers have used foundation sheet $(2.22 \%)$ due lack of casting mold and technical assistance. According to the respondents' perception, bees prefer hives made up of mud \& climbers as they give them heat. Beekeepers keep their colony: under roof, back yard, on the tree in their own farm. Most of them in Daro Labu (Odaa Biyyo \& Sakina PA's) keep in the house; they consider as pet animal - keeping in the house help to domesticate the bees as well most secured from pest and predators.

Concerning the none-beekeepers interviewed, only $38 \%$ of the have participated in beekeeping earlier; and stopped before certain years; the main reason they raised was "Waan baay'ee horsifneef, ijji/budaa namaa nu nyaate raamma'ee bade". According to their perception beekeeping is not for all people; it is given by God - so that only those have that gift practicing. Few of them buy honey for consumption especially for medicine purpose for children cough.
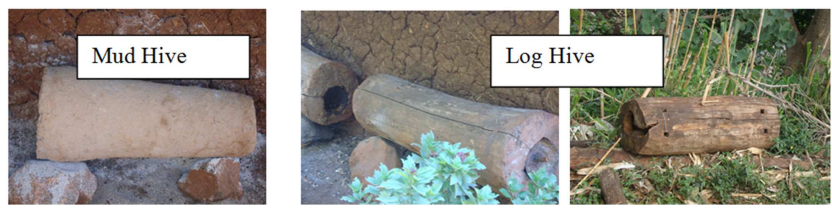

Figure 1. Different types of traditional hives.

\subsection{Traditional Naming of Colony}

All most all of the respondent (96.67\%) categorizes their colonies based on their body size, color, swarming rate, honey production and enemy protection. Accordingly they categorize as: 1) "Red" - selected for it productivity, populate in the hive in short period of time, enemy protection, no frequent swarming and more aggressive, 2) "Shumbure": good in productivity, enemy protection, no frequent swarming, populate in the hive in short period of time and relatively gentle as compared to Red, 3) "Black large" selected for its gentleness - docile and swarm more or brooder help to increase colony number. 4) Few beekeepers said also there are "Birriyyee" (red very small in size) and "Daalacha" which are very scarce today or about to disappear, which were the most productive one. About $79.98 \%$ of the interviewed farmers prefer "Red" and "Shumbure. This is concurrent with the investigation [16] who reported that two categories of o colony by the beekeepers as dark and brown based on body size and color.

\subsection{Honeybee Management Practice}

Most of the respondents have long period experience in traditional beekeeping that passed to them from their ancestor. They highly consider their honeybees, they never look only for honey - have good attention - traditional consideration for their colony.

\subsubsection{Feeding Management}

Of the interviewed farmers $97.33 \%$ of them provide food and water to their colony; types of feed include: sugar, roasted barley, wheat, pea/bean floor, Haricot bean, salt and sugar in combination of two or more than two feed types. Also few farmers $(2.22 \%)$, in addition to the above feed, they provide meat especially fat - like tail of sheep which they consider highly palatable to the bees and hen's meet; and most of the time they proved meat/fat in dearth period and when the population of the colony is getting lower. This report disagree with the report of [7] who reported as honeybees are completely vegetarians. The dearth period: for Daro Labu is December to March and May to August, and for Gemmachis December to mid-February and June to September. Water is provided outside the hive and they add grass or other tin shrub on which bees walk dawn and get accesses of water and in Daro Labu 100\% they provide water throughout the dearth period (lack of water is the most problem in Daro Labu) and only $36 \%$ of them provide water in Gemmachis, as well as, most of the time feed is also provided outside hive in both districts.

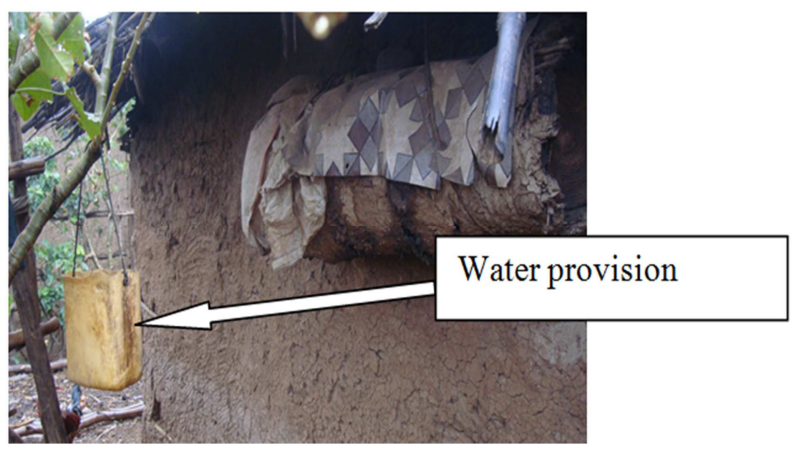

Figure 2. Water provision method for honey bees.

\subsubsection{Colony Attraction, Catching \& Control Method}

The constructed hive of what ever made will smoothen with animal dung, then fumigate/smoke with different plants like Olea africana, Juniperas Procera, permna schimperi, Carissa edulis, wax, smear with goat urine after smoking and some spray perfume and put incense stick in the hive especial female beekeepers. Very few farmers smear internal parts of hive with wax or insert comb to lead the bees to construct combs the way they need. Then the hive hanged on a tree as a way to catch a moving swarm. The investigation agree with the report of [16], who reported that farmers used different plants found in their vicinity and they also use perfume and boswelia papifera to attract swarm in to a new hive.

They spray water, soil or throw cloth or leaf on the moving swarm; after it landed they catch the queen and put in the traditional queen cage, then put in the hive and stayed for few days; the cage have hole through which workers feed her according to their perception, the hole allow worker bees to freely inter the cage and exit but not possible for the queen. 


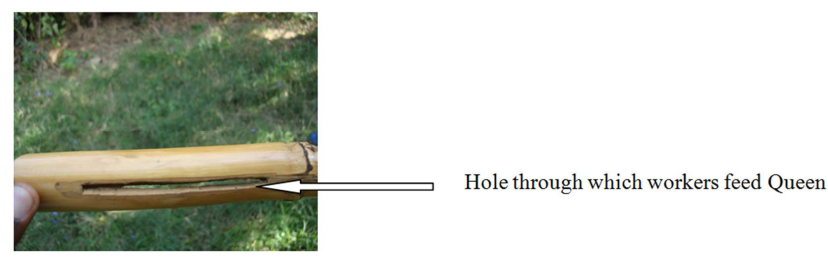

Figure 3. Traditional Queen Cage made of Arundinaria donax.

If the colony is swarming from their own apiary, they know that during high flower flow bees naturally swarm. So that they attend at this time each day, and few of them attend for double sound of queen each night; if there the coming day, they never go any where - ready to catch, when it leave the hive because after leaving the hive they know it will land near there on tree/shrub. [7] Pointed out that early onset of swarming detection have focused on monitoring of sound inside the hive.

Very few beekeepers undertake internal inspection to control swarm by cutting the newly formed queen cell. Moreover, traditional hive is not convenient to undertake internal inspection for such activities. This study is in agreement with the repot of [16]. Some also smoke with a plant called "Hulluuqqoo" to protect production of new queen; they also smoke the hive with this plant to protect wax moth.

\subsection{Traditional Honey Flow Season Identification and Honey Production}

There are about 53,832 honeybee colonies in west Hararghe zone (Livestock agency of the zone), where about 373.6 tones of honey produced per year.

The beekeepers identify honey flow season by the experience they developed through traditional practices. This include: honey smell, insert tin stick, bees' condition - sound and accumulate at entrance, absence of pollen on the leg of bees and astronomic knowledge by looking the moon.

Honey mostly harvested during end of September to November, the main honey flow season. And may be possible to harvest in April and May, but the quantity is much smaller. However, the beekeepers are not sure of their experience of the calendar because of the rain fall not coming as earlier they expect. While harvesting honey, $47.78 \%$ select for combs that containing honey, very few $(3.32 \%)$ select for ripens honey after harvest - accordingly they use that ripenhoney at home for consumption especially for medicine purpose. None of them harvest honey totally; they leave certain amount for their bees to secure their colony maintained for the next season. If they harvest totally they are aware of that their colony starved and will abscond for the coming dearth period. According to the respondents, their colony will abscond if: all the honey harvested, if not supplied with feed and water for dearth period and not cared for enemies.

As it was recorded during the survey, in the sampled districts honey yield varies from districts to districts even between individual beekeepers. So that the average honey yield in the sampled districts from traditional,
transitional/Chefeqa \& box hive was $6.4 \pm 2.63,8 \pm 2.83$ and $13.9 \pm 4.04 \mathrm{~kg}$ respectively. The yield of per hive is agreeing with the finding of Wakeneh et al 2006. Average $\mathrm{kg}$ of honey harvested per household per year was 42.27 \pm 35.29 ranging from $5-170 \mathrm{~kg}$ (by district the amount of honey harvested per year significantly differ at $p$ value 0.05 but not significant within PA of district; Daro Labu $39.11 \pm 32.34 \mathrm{~kg}$ ranges from $5-150 \mathrm{~kg}$ and Gemmachis $45.42 \pm 38$. $11 \mathrm{~kg}$ ranges $6-$ $170 \mathrm{~kg})$. Most of the respondents don't harvest wild honey, because of there in no forest and insignificant amount of the yield.

Some of the methods used by the beekeepers to reduce intensity of sting during honey harvest are like smoking with cow dung, Vernonia, smear their necked body with Senna didymobotrya and Carissa spinarum L., some of them remove all their cloth, other smear their necked body with honey. And method for pain reduction are like eating more honey and rubbing with soil.

\subsubsection{Honey and Bees Wax Storage and Processing}

Honey stored in plastic material and Buqqee/Afaan Oromoo, Qile/Amharic. None of the respondent process honey, all combs that contain honey sold with honey/honey comb. The main reasons are: local market demand supplying honey with comb is expected and simple to detect it is free of adulteration, lack of skill and fail to consider honey processing will improve honey quality.

None of the beekeepers process empty combs in to pure bees wax; about $94.45 \%$ them either throw away or use to smoke with new hive for fumigation purpose. $2.22 \%$ return into hive or use to smoke new hive and 3.33\% smear or attach the comb to lead the bees in the new hive to construct comb the way they need or throw away.

\subsubsection{Honey Consumption, Value and Honey and Honeybee Marketing}

About 373.6 tons of honey produced per year where 127.2 tones $(34 \%)$ of it supplied for the local market demand and the average cost of honey was $150 \mathrm{Birr} / \mathrm{kg}$ where more than four million Birr incurred per year (Livestock Agency of the zone). As to the collected data, $65 \%$ of the honey goes for local market and the rest consumed at home. Honey consumed at home for food and as a medicine. Honey believed that it has high nutritional value and cure many diseases (cold, cough, repair weaken body - during active time of farming due to load of work they flee pain around/under their chest what they call "Hadhooftuu", and honey is the most medicine for that pain and to repair the body).

The most honey quality measure at market is purity which determined by supply of honey as it harvested with its combs, liquidity, test and color - mostly white honey is preferred. On average the farthest distant market place was $29.89 \pm 51.47 \mathrm{~km}$ and the nearest was $2.73 \pm 4.93 \mathrm{~km}$. The market place distance differ between study districts; accordingly the farthest and nearest market place in Daro Labu $40.97 \pm 0.69$ and $1.28 \pm 5.19 \mathrm{~km}$ respectively; and for Gemmachis the farthest and nearest market place are 


\section{$17.18 \pm 7.89 \mathrm{~km}$ and $2.72 \pm 4.93 \mathrm{~km}$ respectively.}

Mostly honey taken to market by female; however the decision on income made by husband and the income will be used to buy household consumption like spice - onion, salt and cloth, small ruminant, also due to honey harvested when no crop in the field harvested - it is important cash source to buy exercise book and school fee for their children/student which save sell live animal. Of the survey sampled respondents $15.56 \%$ of them sell honeybee colony; and the average colony price was 800.33 ETB ranging from $800-100$ ETB depending on the population of the colony and type (Red and "Shumbure" are selected for their productivity, prolificacy, enemy protection and less tendency of swarming).

\subsection{Honeybee Enemies \& Traditional control Measure}

Table 1. The most important honeybee enemies identified during the study were ranked as shown below.

\begin{tabular}{lll}
\hline S. no & Bee enemies & Rank \\
\hline 1 & Small ant & 1 \\
2 & Birds & 2 \\
3 & Honey badger & 6 \\
4 & Butter fly & 4 \\
5 & Wax moth & 3 \\
6 & Mice & 7 \\
7 & Silmi kannisa & 5 \\
8 & Adeera kannisa & 8 \\
9 & Spider & 9 \\
10 & Lizard & 11 \\
11 & Roach & 10 \\
\hline
\end{tabular}

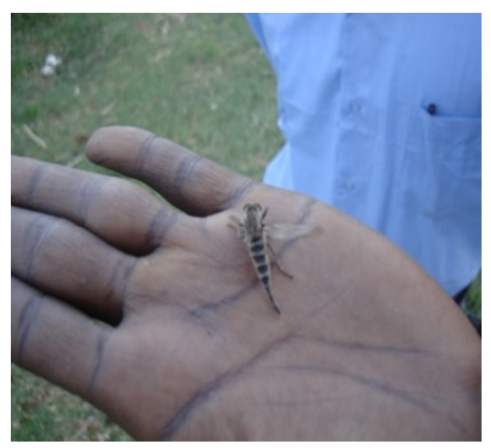

Figure 4. Honey bees enemy that feed on bees at foraging.

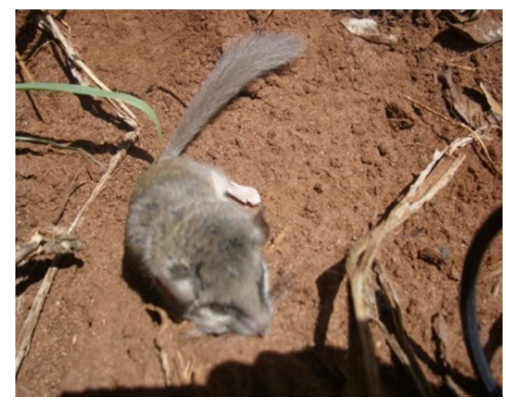

Figure 5. Mouse that feed honey bees.

Beekeepers have developed their own protection method. Some of this method includes:

a) Honey badger - Use dog, fire burning, fence with thorn

b) Small ant dusting ash under the hive stand or smear the hive stand with burned oil gas from miller,

c) Birds - killing, keeping, putting man like picture near the hive, but non of these method hive controlled birds because they feed on bees at foraging

d) Butterfly and mice - killing, smaller entrance

e) Wax moth- fumigate/smoke the hive with Vernonia, dried cow dung and Olea africana"

f) Spider and roach - cleaning

\subsection{Trend of Colony Population and Hive Occupation}

The beekeepers were also interviewed for the beekeeping trend. According to their response $(92.23 \%)$ few years back honeybee colonies were abundant - observed while migrating, and few of their hives were unoccupied by bees, but today almost half are un occupied. And $60 \%$ of the respondents are not expanding their beekeeping enterprise due to poor productivity. However, more than $65.6 \%$ consider beekeeping as one of the significant income generating sub sector. The main reasons for decreasing beekeeping trend and colony per farmers raised were: Small size of land owned - lack separate site for their apiary, deforestation and drought - lack of water, low production level, lack of attention, lack of extension service and improvement.

\subsection{Agro-chemicals Poisoning}

Generally in western Harargea, due to small size of land owned, they inter-crop different food crops; for which use of herbicide is very minimal and no much comment by the respondents. However use of DDT on chat by farmers, anti malaria and Flora Eco-power used chemical on Caster oil plant (Qobboo) are causing /have caused sound effect on honeybees. And Croton macrostachyus, is the natural honeybee poisoning plant identified in the area.

For example, according to the survey result in Daro Labu, the chemical used by Flora Eco-power alone caused on average total loss of 2.22 colonies and weakened 3.51 colonies per beekeepers. Even a year after the use of the chemical, the bees hatched without wing or deformed; which may be due to the residual effect.

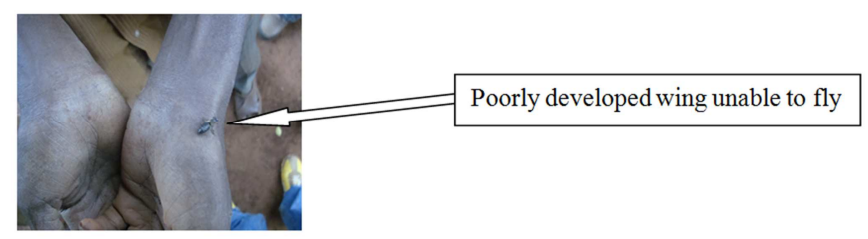

Figure 6. Removing queen wings when they catch the swarm.

\subsection{General Beekeeping Constraints Identified}

The major constraints supposed to limit the development and sustainability of beekeeping in selected districts as mentioned by both beekeeper and non-beekeeper households includes: Lack of improved beekeeping technologies and training, lack of extension service (only $2.041 \%$ of honeybee colonies are found in the improved hive and only $16.7 \%$ of 
the beekeepers have got extension service for promoting improved beekeeping system by development agent where $70.33 \%$ of them were from Gemmachis and the rest from Bortae PA of Daro Labu). Lack of selected line among the population - according to the respondents (90\%) there is big difference among the population at their hand - some are very aggressive, some are very productive, some are only rear brood - poor in honey production. Lack of skilled man power, Deforestation \& shortage of bee forage (problem of

bee colony and honey was prevailed after the Guuguu forest was burned which extends from Arsi zone to Baddessa district of west Hararghe), Drought - lack of water, Lack of knowledge how to process honey and bees wax, wax considered as value less, lack of knowledge of pollination service of honeybees (Honeybees are known only for the product honey) Honeybee enemies (pest and predators), Small land size and Agro-chemicals.

Beekeepers and the none-beekeepers were separately interviewed for the strength, weakness, opportunities and threats on beekeeping.

Table 2. Farmer's strength, weakness. Opportunity and Threats in the study areas.

\begin{tabular}{|c|c|c|c|c|}
\hline Farmers & strength & Weakness & opportunities & Threats \\
\hline Beekeepers & $\begin{array}{l}\text { Honey have nutritional \& medicinal } \\
\text { value (especially for children) } \\
\text { Experience of long period in traditional } \\
\text { beekeeping } \\
\text { Low land in put \& not lobar consumer } \\
\text { Bees sting it self is cure against many } \\
\text { disease }\end{array}$ & $\begin{array}{l}\text { Low product, lack of } \\
\text { any training, } \\
\text { extension service or } \\
\text { technical support } \\
\text { Need separate place }\end{array}$ & $\begin{array}{l}\text { Have good market price } \\
\text { Relatively drought tolerant as } \\
\text { compared to cattle } \\
\text { some degraded mountains areas } \\
\text { are now protected and enclosed } \\
\text { good source of bee forage }\end{array}$ & $\begin{array}{l}\text { Deforestation, drought-lack of water } \\
\text { small land size bees may disturb human } \\
\& \text { livestock } \\
\text { pests \& predators like birds \& small ant } \\
\text { Lack tree for hive construction } \\
\text { Availability and cost of box hive and } \\
\text { other equipments }\end{array}$ \\
\hline $\begin{array}{l}\text { None- } \\
\text { beekeepers }\end{array}$ & $\begin{array}{l}\text { honey have good demand at market } \\
\text { low land input }\end{array}$ & $\begin{array}{l}\text { Lack of knowledge, } \\
\text { bee phobia, } \\
\text { No bee colony }\end{array}$ & $\begin{array}{l}\text { it is good if the government } \\
\text { provide us bee colony }\end{array}$ & Drought \\
\hline
\end{tabular}

\section{Conclusion and Recommendation}

Beekeepers have rich indigenous knowledge \& experience of beekeeping in the surveyed area. Identification and integration of such knowledge with improved beekeeping technologies will improve the productivity of the sub sector thereby its sustainability. As it was explained beekeeping is relatively marginalized as compared to other agricultural sub sector and lack of improvement and possessing of hive products. Training on seasonal colony management, different hive product harvesting, processing and storage is very important to capacitate the beekeepers and for the improvement of hive productivity both in quantity and quality. The beekeepers have good experiences in feeding their colony by providing supplemental and amino acid substitute of crop and animal source feeds during dearth period. It is important to verify bees are not vegetarian and the effect of animal source amino acids as pollen substitute on the performance of honeybees. Also this study recommend further for study the appropriate ratio and the effectiveness of the different types of feed provided by the local beekeepers to develop novel feeds and method of feeding bees with supplemental and pollen substitutes. Screening of potential bee forage and distribution of it to the beekeepers will alleviate the shortage of bee forage. Also it is important to collect and characterize the traditionally categorized honeybee colonies for their merit for selection and improve their potential through breeding and/or appropriate management practices

\section{Acknowledgements}

The authors acknowledged the Oromia Agricultural Research Institute, Mechara Agricultural Research Center for allocating budget and executing resource for the study and those of you that have been given constructive comments for the improvement of the paper.

\section{References}

[1] Amsalu Bezabah and Garemew Iticha, 1998. Oromia Agricultural coordination Survive, Addis Ababa, Ethiopia.

[2] Ayalew Kassaye and Gezahegn Tadesse. 1991. Suitability classifi cation in apicultural development. MoA (Ministry of Agriculture), Addis Ababa, Ethiopia.

[3] Ayalew Kassaye. 1990. The Honeybee (Apis mellifera) of Ethiopia: A Morphometric Study. M. Sc. Thesis, Agricultural University of Norway, Norway.

[4] Ayalew Kassaye. 2001. Promotion of beekeeping in rural sector of Ethiopia: Proceedings of the third National Annual Conference of Ethiopian Beekeepers Association (EBA), September 3-4, 2001, Addis Ababa, Ethiopia, pp. 52-58.

[5] Ayalew, K. (1994). Beekeeping manual. Agri-Service Ethiopia, Addis Ababa Countries. Lynne Rienner Publishers, Boulder, London: p. 57.

[6] Dadant and Songs, 1975. The Hive and the Honey Bee. A new Book on Beekeeping which continuous the traditional Langstroth on the Hives and the Honey Bee.

[7] David Aston, Ivor Davis and Paul Metcalf January 2009. Honeybee Health Research Concepts.

[8] documentation of indigenous knowledge of beekeeping practice. Proceedings of the $14^{\text {th }}$ Ethiopian society of animal production September 5 - 72006 Addis Ababa, Ethiopia.

[9] Gebreyesus Mamo, 1976. Apiculture in Tropical Climate, BRA London.

[10] Girma Deffar, 1998. Non-Wood Forest Products in Ethiopia. ECFAO Partnership Programme (1998-2000). Addis Ababa. pp. 1-5. 
[11] Kerealem, 2009. Bee keeping in the Amhara region rd. Ethiopian beekeeping association (EBA).: 52-58.

[12] Ministry of Agriculture and Rural Development (MOARD), Government of Ethiopia, December 2008, Addis Ababa Ethiopia.

[13] MoARD (Ministry of Agriculture and Rural Development). 2008. The third residue monitoring plan for honey from Ethiopia. Produced by members of the Ethiopian Honey and Beeswax Producers and Exporters Association (EHBPEA). Addis Ababa Ethiopia.
[14] Nuru Adgaba. 1999. Quality state of grading Ethiopian honey. In: Proceedings of the fi rst national conference of the Ethiopian Beekeepers Association, Addis Ababa, Ethiopia.

[15] Nuru Adgaba. 2002. Geographical races of the Honeybees (Apis mellifera L.) of the Northern Regions of Ethiopia. Ph.D dissertation. Rhodes University, South Africa.

[16] Wakeneh Abebe, Sebsibie Zuber and Enani Bashawurad, 2006. Identification. 